\title{
Aplikasi Perancang Abstraksi Verilog Mesin Keadaan Terbatas Otomatis
}

(Automatic Finite State Machine to Verilog Abstraction Application)

\author{
FAIRUZ AZMI
}

\begin{abstract}
ABSTRAK
Saat ini, hampir semua perangkat elektronik menggunakan prosesor di dalamnya. Dalam sebuah prosesor, terdapat bagian control unit yang berfungsi mengatur operasi dari komponen-komponen di dalam prosesor. Control unit merupakan sebuah mesin keadaan terbatas atau disebut finite state machine (FSM). Rangkaian FSM dapat disintesis secara manual ataupun secara otomatis menggunakan bahasa abstraksi Verilog. Dalam penelitian ini, dibuat sebuah aplikasi yang dapat membantu pengguna merancang FSM dan selanjutnya menyimpannya dalam format Verilog. Aplikasi yang dibuat secara fungsional dapat berjalan dengan kesesuaian $100 \%$ dan mampu untuk membuat rancangan Verilog untuk FSM dengan berbagai model dan teknik pengkodean state. Simulasi modul Verilog yang dihasilkan juga sesuai dengan spesifikasi rangkaian FSM yang dirancang.
\end{abstract}

Kata kunci: Control unit, FSM, Verilog.

\section{ABSTRACT}

Today, almost all electronic devices use processors. Inside a processor, there is a control unit that controls the operation of the components in the processor. The control unit also called the finite state machine (FSM). FSM circuits can be synthesized manually by hand or automatically using the Verilog abstraction language. In this research, an application is made that can help users design FSM and then export it to Verilog format. Functionally, the applications is $100 \%$ complied with the requirements and are able to create Verilog designs for FSM with various FSM models and state encoding techniques. The resulting Verilog module simulation also conforms to the designed FSM circuit specifications.

Keywords: Control unit, FSM, Verilog.

\section{PENDAHULUAN}

Saat ini, hampir semua perangkat elektronik menggunakan prosesor di dalamnya, baik itu komputer, jam tangan pintar (smartwatch), bahkan berbagai perangkat elektronik rumah tangga seperti lemari es dan pendingin ruangan juga menggunakan prosesor (Martindale, 2021). Prosesor atau sering disebut central processing unit (CPU) berfungsi untuk memproses dan mengeksekusi instuksiinstruksi dan berperan sebagai otak dari perangkat elektronik yang membutuhkan proses komputasi.
Rancangan sebuah prosesor dapat dibagi ke dalam dua bagian, yaitu bagian datapath dan bagian control unit (Hwang, 2005; Ledin, 2020), sebagaimana ditunjukkan pada Gambar 1. Datapath berfungsi untuk menangani segala operasi yang berhubungan dengan data, termasuk di dalamnya unit fungsional seperti arithmetic-logic unit (ALU), register, dan bus untuk mentransmisikan data antar komponen di dalam datapath. Sedangkan control unit atau disebut controller berfungsi untuk mengatur seluruh operasi di datapath dengan memberikan sinyal kendali yang sesuai di waktu yang tepat. Untuk setiap satuan waktu, control unit berada dalam suatu kondisi (state), yang secara fisik merupakan isi dari sebuah state memory. Control unit beroperasi dengan 
cara bertransisi dari sebuah state ke state lainnya, yang berubah setiap siklus clock. Berdasarkan perilaku tersebut, maka control unit juga sering disebut sebagai sebuah mesin keadaan terbatas atau finite state machine (FSM).

FSM merupakan nama lain dari sebuah rangkaian logika sekuensial. Nama FSM lebih sering digunakan dalam literatur teknis (Brown \& Vranesic, 2014). Rangkaian sekuensial adalah rangkaian yang keluarannya bergantung kepada kondisi keluaran di waktu lampau, selain dipengaruhi juga oleh nilai masukan saat ini sebagaimana di rangkaian logika kombinasional. Dalam banyak kasus, rangkaian sekuensial dikendalikan menggunakan sinyal clock sebagai komponen pewaktu, sehingga rangkaian sekuensial lebih sering merujuk kepada rangkaian sekuensial sinkron, selain rangkaian sekuensial asinkron yang bekerja tanpa ada pengendali sinyal pewaktu.

Sebuah FSM direalisasikan menggunakan gabungan rangkaian kombinasional dan flipflop (Brown \& Vranesic, 2014). Untuk merancang sebuah FSM, dibutuhkan beberapa tahapan, diantaranya membuat diagram transisi keadaan (state diagram), membuat tabel transisi (state table), kemudian memilih tipe flip-flop dan merealisasikan rangkaian (Bucaro, 2019). Dalam proses perancangan perangkat keras digital, perancang integrated circuit (IC) membutuhkan umpan balik yang cepat dari hasil rancangan yang dibuatnya untuk menentukan kesesuaian rancangan dibandingkan dengan spesifikasi sistem yang telah ditentukan (Weste \& Harris, 2011). Menerjemahkan diagram blok dan FSM menjadi rangkaian skematik akan menghabiskan banyak waktu dan dapat meningkatkan peluang terjadinya error dalam proses verifikasi. Oleh karena itu, diperlukan suatu metode untuk merancang di level atas dan segera mengetahui apakah perlu dilakukan perancangan ulang berdasarkan hasil verifikasi rancangan top module. Untuk merancang abstraksi rangkaian, digunakan bahasa yang dapat mendeskripsikan sebuah sistem digital, yaitu hardware description language (HDL). Awalnya, HDL hanya digunakan untuk keperluan dokumentasi dan simulasi, tetapi saat ini HDL juga dapat digunakan untuk mensintesis rangkaian digital berdasarkan abstraksi yang telah dibuat, sehingga seluruh proses perancangan dapat dilakukan secara otomatis. Salah satu bahasa HDL yang umum digunakan saat ini adalah Verilog, bahasa yang distandarkan sebagai IEEE standard 1364-1995 (Thomas \& Moorby, 2013). Standar Verilog terbaru saat ini adalah IEEE standard 13642005 (IEEE Computer Society, 2006).

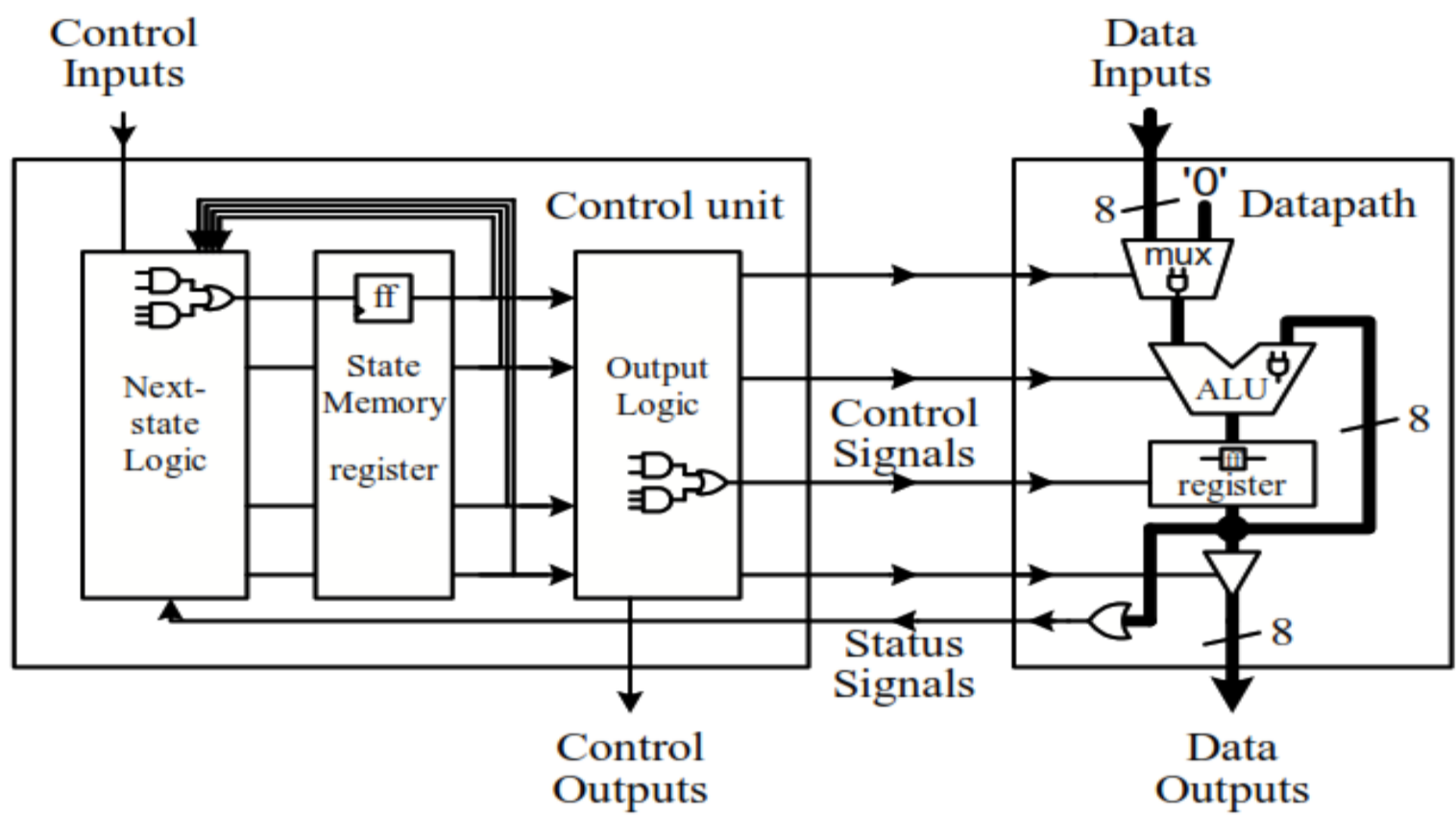

GAMBAR 1. Skema Sebuah Prosesor

(Hwang, 2005) 
Dalam penelitian ini, dibuat sebuah aplikasi desktop yang dapat membantu perancang IC untuk membuat modul FSM secara visual menggunakan tabel dan ditampilkan dalam bentuk diagram. Selanjutnya, program secara otomatis akan menerjemahkan deskripsi Verilog dari diagram yang telah dirancang untuk selanjutnya dapat disimulasikan di aplikasi $H D L$ simulator, dan lebih lanjut modul tersebut dapat disintesis untuk diimplementasikan baik di field programmable gate array (FPGA) maupun sebagai sebuah application specific integrated circuit (ASIC).

\section{METODE PENELITIAN}

Aplikasi FSM Designer dibangun menggunakan bahasa pemrograman $\mathrm{C \#}$ di atas platform .NET Framework 4.7.2. Bahasa C\# merupakan bahasa pemrograman yang sederhana, modern, serbaguna, serta berorientasi objek (Hejlsberg et al., 2002). Aplikasi yang digunakan dalam pembuatan aplikasi ini adalah Microsoft Visual Studio 2019. Aplikasi dibuat dalam bentuk aplikasi
Windows Form dan berjalan di sistem operasi Windows 10.

Aplikasi FSM Designer memiliki tiga komponen utama yang ditampilkan dalam satu jendela aplikasi. Komponen utama aplikasi meliputi tabel data untuk mengisi state table, komponen untuk menggambar diagram di jendela aplikasi, dan komponen penerjemah tabel data menjadi bahasa Verilog. Komponen tabel data memanfaatkan library standar dari bahasa C\# dan ditampilkan di komponen DataGridView. Untuk menggambar diagram, digunakan library Microsoft Automatic Graph Layout (MSAGL), library untuk .NET Framework yang dikembangkan di Microsoft untuk membuat dan menampilkan graf (Nachmanson et al., 2021). Untuk menerjemahkan tabel data menjadi bahasa Verilog, dibuat sebuah class yang berfungsi untuk membangkitkan sintaks bahasa verilog berdasarkan kondisi-kondisi yang telah diterapkan di tabel data dan di halaman utama aplikasi FSM Designer. Secara umum, aktivitas dalam aplikasi FSM Designer dapat dilihat pada Gambar 2.

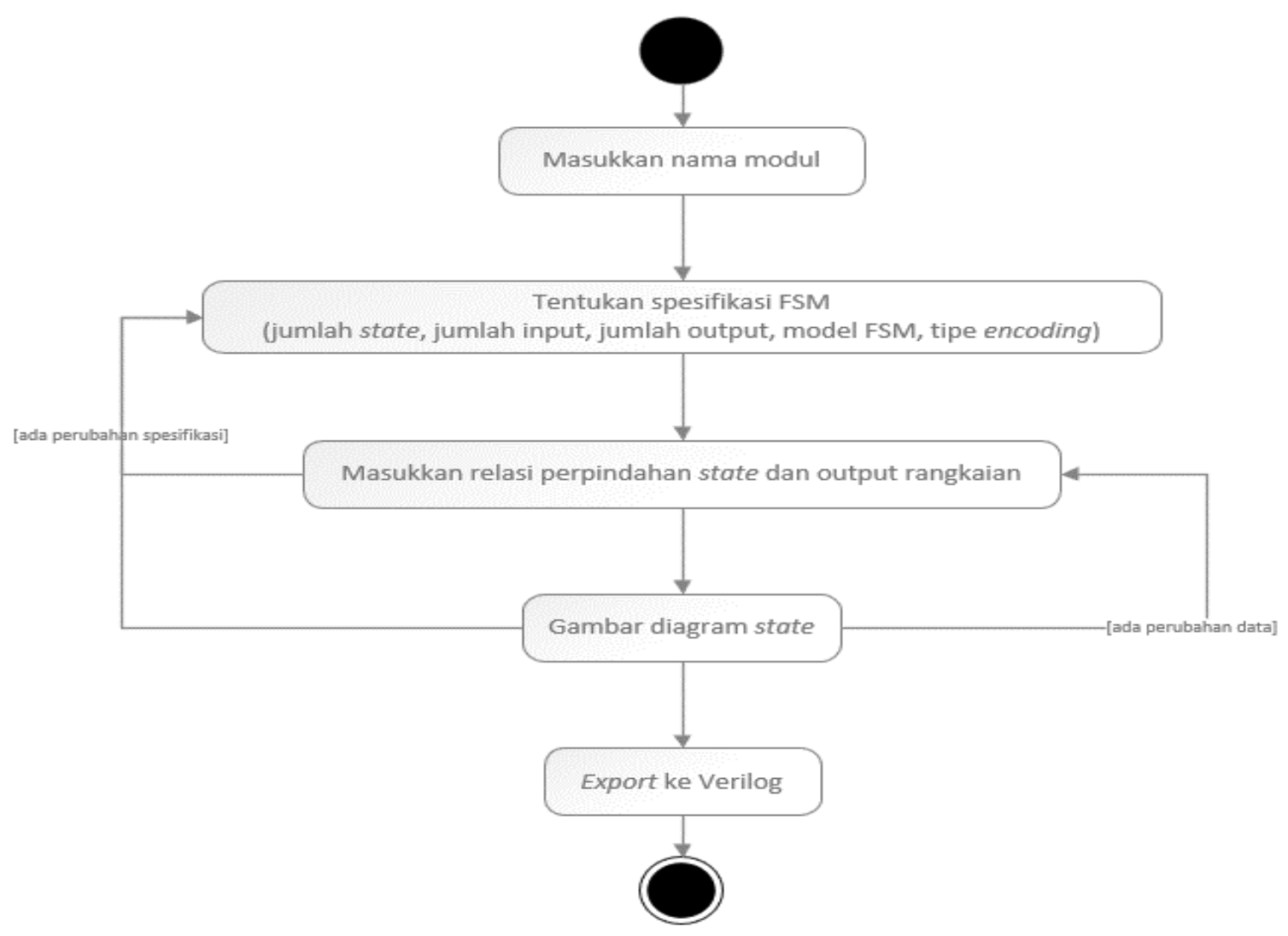


Kondisi terkini dari sebuah FSM disimpan di dalam sebuah state memory. State memory secara fisik adalah kumpulan flip-flop yang banyaknya sebanding dengan panjang kode state. Untuk mengkodekan state, terdapat tiga cara yang umum digunakan, yaitu binary encoding, gray code encoding, dan one-hot encoding (La Meres, 2017). Pemilihan tipe pengkodean state dapat mempengaruhi panjang ukuran state memory. Pengkodean dengan binary encoding dan gray code encoding memerlukan panjang kode state yang sama, sebagaimana ditunjukkan pada persamaan (1). Kode state untuk binary encoding merupakan nilai biner sesuai persamaan (2), sedangkan kode untuk gray code encoding ditunjukkan pada persamaan (3). Penggunaan gray code encoding bermanfaat untuk meminimalkan perubahan nilai flip-flop dalam state memory jika urutan perpindahan state dalam FSM bersifat linier. Teknik pengkodean state yang juga umum digunakan dalam perancangan FSM adalah one-hot encoding. Metode ini menerapkan kode dari state dengan membuat seluruh nilai flip-flop dalam state memory dalam kondisi logika ' 0 ', kecuali satu buah flipflop, yang dikatakan sebagai "hot" (Brown \& Vranesic, 2014). Berbeda dengan metode binary dan gray code encoding yang menitikberatkan efisiensi pada jumlah flip-flop yang digunakan di rangkaian, metode one-hot encoding membuat rangkaian logika next-state menjadi lebih sederhana (La Meres, 2017), sehingga membutuhkan waktu yang lebih cepat dibanding teknik pengkodean lainnya. Untuk mengodekan state menggunakan metode onehot encoding dibutuhkan flip-flop sebanyak jumlah state, dan kode state ditunjukkan di persamaan (4). Tabel 1 menunjukkan contoh pengkodean state.

$$
\left.L={ }^{2} \log n S\right\rceil
$$

$S_{i}=\operatorname{bin}(i, L) \quad, 0 \leq i<n S$

$S_{i}=\operatorname{bin}(i \oplus\lfloor i / 2\rfloor, L), 0 \leq i<n S$

$S_{i}=\operatorname{bin}\left(2^{i}, n S\right) \quad, 0 \leq i<n S$

dengan $\mathrm{L}=$ panjang kode state, $\mathrm{nS}=$ jumlah state dalam FSM, Si = kode state di urutan $\mathrm{i}$ dalam FSM.

Secara umum, rangkaian FSM terdiri dari dua rangkaian kombinasional dan sebuah state memory yang berupa flip-flop (Donzellini et al., 2019). Rangkaian kombinasional dalam FSM berfungsi untuk menentukan nilai masukan dari state memory untuk mengubah state yang disebut next-state logic. Selain itu, juga terdapat rangkaian kombinasional untuk menentukan nilai keluaran dari FSM, yang disebut output logic. FSM bekerja dengan mengubah isi state memory yang disebabkan oleh next-state logic yang sensitif terhadap input rangkaian. Selanjutnya, melalui rangkaian output logic yang sensitif terhadap state memory, output rangkaian akan dihasilkan.Terdapat dua model FSM, yaitu Moore dan Mealy. Keluaran FSM Moore hanya bergantung dari isi state memory, sedangkan FSM Mealy, selain sensitif terhadap state memory, juga ada pengaruh langsung dari masukan FSM untuk mengubah keluaran. Dalam proses sintesis, perbedaan model Moore dengan Mealy dapat dilihat pada bagian output logic. Masukan output logic untuk FSM Moore hanya berasal dari keluaran state memory, sedangkan masukan output logic untuk FSM Mealy berasal dari keluaran state memory dan juga masukan dari rangkaian FSM. Untuk spesifikasi yang sama, FSM Mealy memiliki lebih sedikit state dibanding FSM Moore, tetapi dengan output logic yang lebih kompleks (Brown \& Vranesic, 2014).

TABEL 1. Contoh Pengkodean untuk Enam Buah State

\begin{tabular}{cccc}
\hline \multirow{2}{*}{ State } & \multicolumn{3}{c}{ Kode State } \\
\cline { 2 - 4 } & Binary & Gray Code & One-hot \\
\hline A (i=0) & 000 & 000 & 000001 \\
B (i=1) & 001 & 001 & 000010 \\
C (i=2) & 010 & 011 & 000100 \\
D (i=3) & 011 & 010 & 001000 \\
E (i=4) & 100 & 110 & 010000 \\
F (i=5) & 101 & 111 & 100000 \\
\hline
\end{tabular}


Setelah menentukan parameter spesifikasi sistem, selanjutnya adalah menerjemahkan rancangan yang telah dibuat ke dalam abstraksi Verilog. Referensi lengkap mengenai sintaks dan struktur bahasa Verilog dapat dilihat di standar IEEE 1364-2005 oleh IEEE Computer Society (2006). Sedangkan panduan cepat mengenai penggunaan Verilog dapat dilihat di tulisan Sutherland (2001). Templat dari kode Verilog FSM dapat dilihat di pseudocode berikut ini:

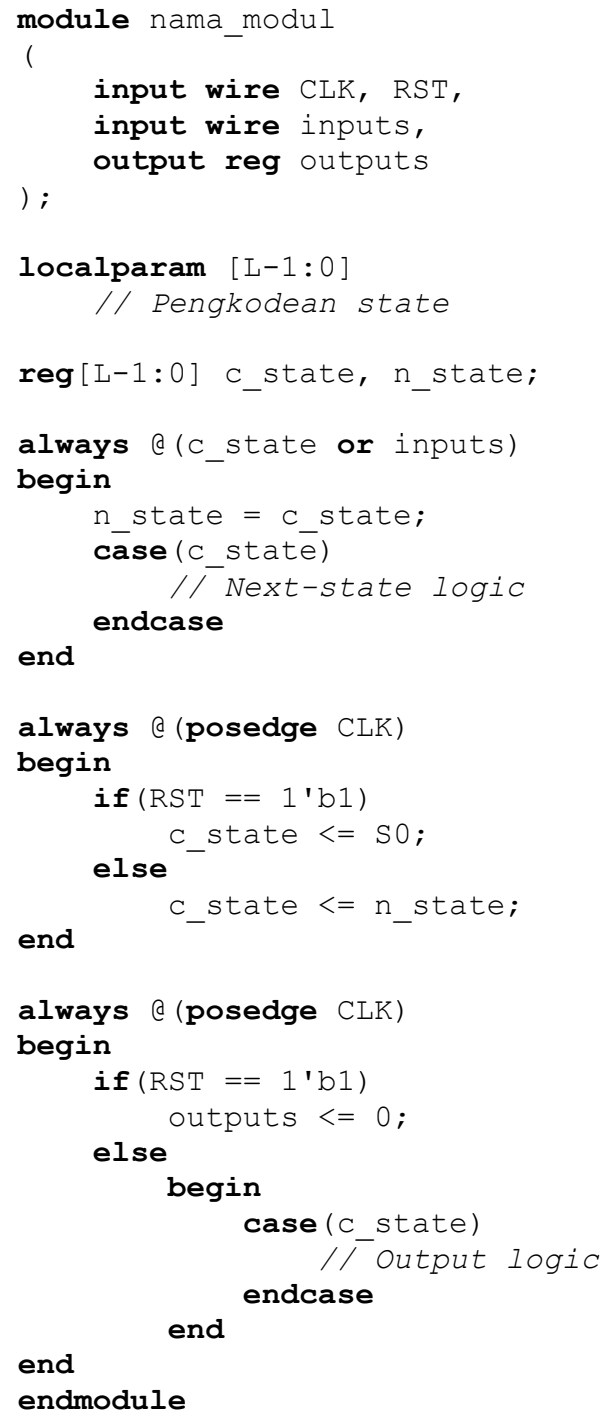

Abstraksi Verilog disimpan dalam sebuah file dengan ekstensi ".v". File disimpan dengan nama yang sama dengan nama modul yang dibuat. Hal ini untuk mengakomodasi beberapa aplikasi HDL simulator dan synthesizer yang mengharuskan penamaan file yang sama dengan nama modul yang dibuat.

\section{HASIL DAN PEMBAHASAN}

Aplikasi FSM Designer dapat berjalan dengan baik di komputer dengan sistem operasi Windows 10 atau minimal Windows 7 yang terpasang .NET Framework 4.7.2. Tampilan aplikasi FSM Designer dapat dilihat di Gambar 3. Untuk menguji kesesuaian kinerja aplikasi dengan spesifikasi yang dirancang, dilakukan pengujian fungsional, yang meliputi pengujian ketepatan aplikasi dalam berinteraksi dengan pengguna. Selanjutnya, untuk menguji ketepatan hasil penerjemahan rangkaian ke bahasa Verilog, dilakukan uji simulasi modul Verilog yang dihasilkan menggunakan aplikasi Modelsim.

\section{Pengujian fungsional aplikasi}

Tabel 2 menunjukkan hasil pengujian fungsional dari aplikasi FSM Designer. Berdasarkan Tabel 2, dapat dilihat bahwa seluruh fungsi utama dari aplikasi FSM Designer berjalan sesuai dengan rancangan. Kesalahan-kesalahan yang terjadi ditangani secara langsung dengan menampilkan pesan kesalahan kepada pengguna, sehingga pengguna dapat langsung memperbaiki tanpa harus memaksa aplikasi untuk dihentikan.

\section{Simulasi file Verilog}

File Verilog yang dihasilkan diuji kesesuaiannya dengan aplikasi HDL simulator. Terdapat banyak aplikasi yang dapat mensimulasikan Verilog. Dalam penelitian ini, digunakan aplikasi Modelsim.

File Verilog yang dihasilkan beragam sesuai dengan kondisi yang telah ditetapkan di dalam Aplikasi FSM Designer. Kondisi-kondisi tersebut meliputi jumlah state, model FSM, jumlah input, jumlah output, jenis pengkodean state, serta penggunaan masukan untuk keperluan me-reset FSM. Berbagai kondisi tersebut disimulasikan dan menunjukkan bahwa $100 \%$ hasil simulasi sesuai dengan rancangan. Hasil pengujian simulasi Verilog dapat dilihat pada Tabel 3.

\section{Analisis hasil sintesis}

File Verilog yang dihasilkan disintesis menggunakan aplikasi Intel Quartus Prime. Sebagai contoh, dilakukan analisis untuk membuat file Verilog dari diagram transisi sebuah FSM yang ditunjukkan pada Gambar 4.

Diagram tersebut menggambarkan transisi keadaan untuk rangkaian detektor sekuensial 
yang akan menghasilkan keluaran logika '1' jika terdeteksi urutan masukan logika '1' minimal dua kali berturut-turut. Dengan proses manual, rangkaian FSM yang terbentuk berdasarkan diagram transisi tersebut menggunakan metode binary encoding dapat dilihat pada Gambar 5.

TABel 2. Hasil Pengujian Fungsional Aplikasi FSM Designer

\begin{tabular}{|c|c|c|c|c|}
\hline No. & Parameter uji & Hasil yang diharapkan & Hasil pengujian & Keterangan \\
\hline 1 & $\begin{array}{l}\text { Aturan } \\
\text { penamaan } \\
\text { modul }\end{array}$ & $\begin{array}{l}\text { Nama modul hanya boleh } \\
\text { terdiri dari alfabet [A..Z, a..z], } \\
\text { numerik [0..9], dan garis bawah } \\
\text { (_), serta tidak boleh diawali } \\
\text { oleh numerik. }\end{array}$ & $\begin{array}{l}\text { Saat diberikan masukan nama } \\
\text { modul selain alfanumerik dan } \\
\text { garis bawah, atau jika dimulai } \\
\text { dengan numerik, maka akan } \\
\text { mengeluarkan pesan dan meminta } \\
\text { pengguna untuk mengganti nama } \\
\text { modul. }\end{array}$ & Sesuai \\
\hline 2 & $\begin{array}{l}\text { Memperbarui } \\
\text { tabel state }\end{array}$ & $\begin{array}{l}\text { Diagram state akan } \\
\text { menyesuaikan isi tabel state. }\end{array}$ & $\begin{array}{l}\text { Diagram state sesuai dengan isi } \\
\text { tabel state. }\end{array}$ & Sesuai \\
\hline 3 & $\begin{array}{l}\text { Klik "Export to } \\
\text { Verilog" }\end{array}$ & $\begin{array}{l}\text { Aplikasi menulis file Verilog } \\
\text { sesuai spesifikasi yang dipilih } \\
\text { dan juga isi tabel state. }\end{array}$ & $\begin{array}{l}\text { File Verilog ditulis denga nama } \\
\text { sesuai nama modul dan isi sesuai } \\
\text { dengan isi tabel state dan } \\
\text { spesifikasi yang ditetapkan. }\end{array}$ & Sesuai \\
\hline
\end{tabular}

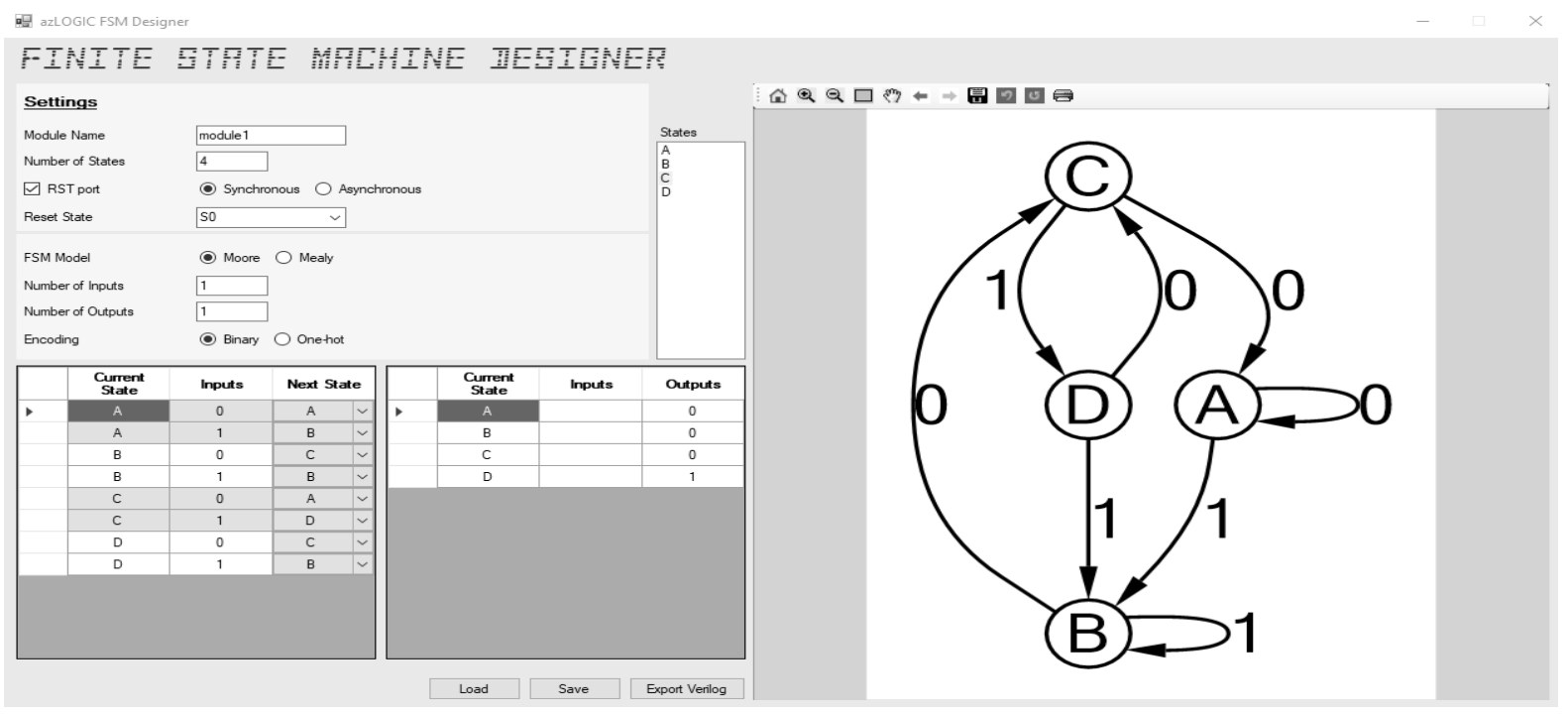

GAMBAR 3. Tampilan Aplikasi FSM Designer

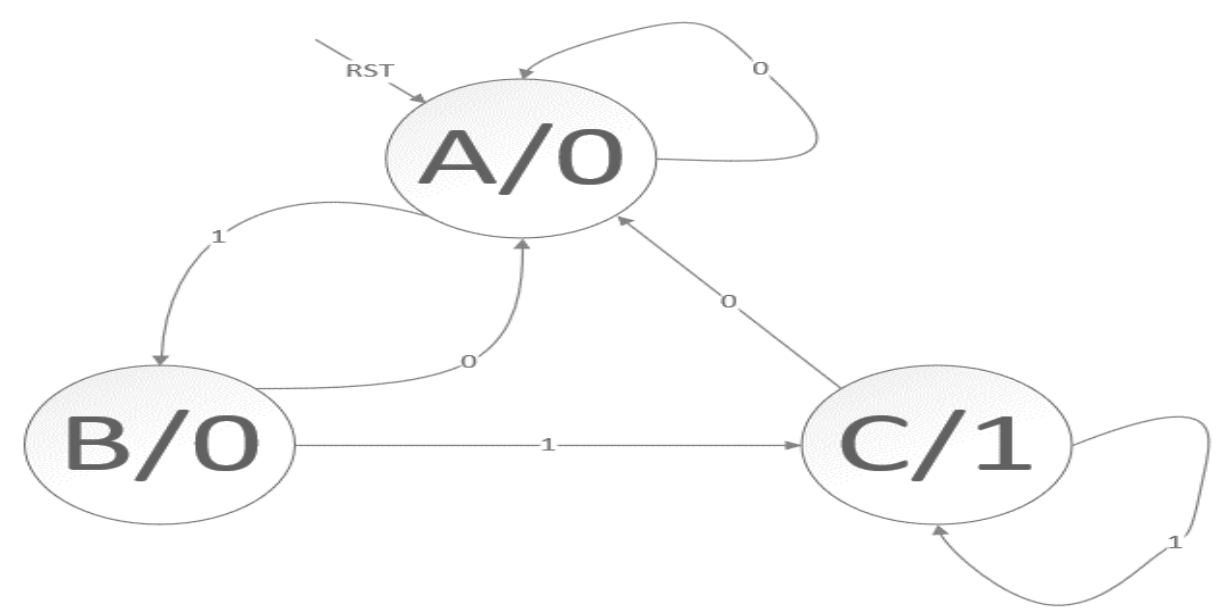

GAMBAR 4. Diagram Transisi Keadaan Untuk Mendeteksi Urutan Input "11" 
TABel 3. Hasil Pengujian Simulasi File Verilog

\begin{tabular}{|c|c|c|}
\hline No. & Spesifikasi FSM & Keterangan \\
\hline \multirow[t]{9}{*}{1} & \multicolumn{2}{|l|}{ Tanpa reset } \\
\hline & \multicolumn{2}{|l|}{ a. Model Moore } \\
\hline & Binary encoding & Sesuai \\
\hline & Gray code encoding & Sesuai \\
\hline & One-hot encoding & Sesuai \\
\hline & \multicolumn{2}{|l|}{ b. Model Mealy } \\
\hline & Binary encoding & Sesuai \\
\hline & Gray code encoding & Sesuai \\
\hline & One-hot encoding & Sesuai \\
\hline \multirow[t]{9}{*}{2} & \multicolumn{2}{|l|}{ Dengan synchronous reset } \\
\hline & \multicolumn{2}{|l|}{ a. Model Moore } \\
\hline & Binary encoding & Sesuai \\
\hline & Gray code encoding & Sesuai \\
\hline & One-hot encoding & Sesuai \\
\hline & \multicolumn{2}{|l|}{ b. Model Mealy } \\
\hline & Binary encoding & Sesuai \\
\hline & Gray code encoding & Sesuai \\
\hline & One-hot encoding & Sesuai \\
\hline \multirow[t]{9}{*}{3} & \multirow{2}{*}{\multicolumn{2}{|c|}{$\begin{array}{l}\text { Dengan asynchronous reset } \\
\text { a. Model Moore }\end{array}$}} \\
\hline & & \\
\hline & Binary encoding & Sesuai \\
\hline & Gray code encoding & Sesuai \\
\hline & One-hot encoding & Sesuai \\
\hline & \multicolumn{2}{|l|}{ b. Model Mealy } \\
\hline & Binary encoding & Sesuai \\
\hline & Gray code encoding & Sesuai \\
\hline & One-hot encoding & Sesuai \\
\hline
\end{tabular}

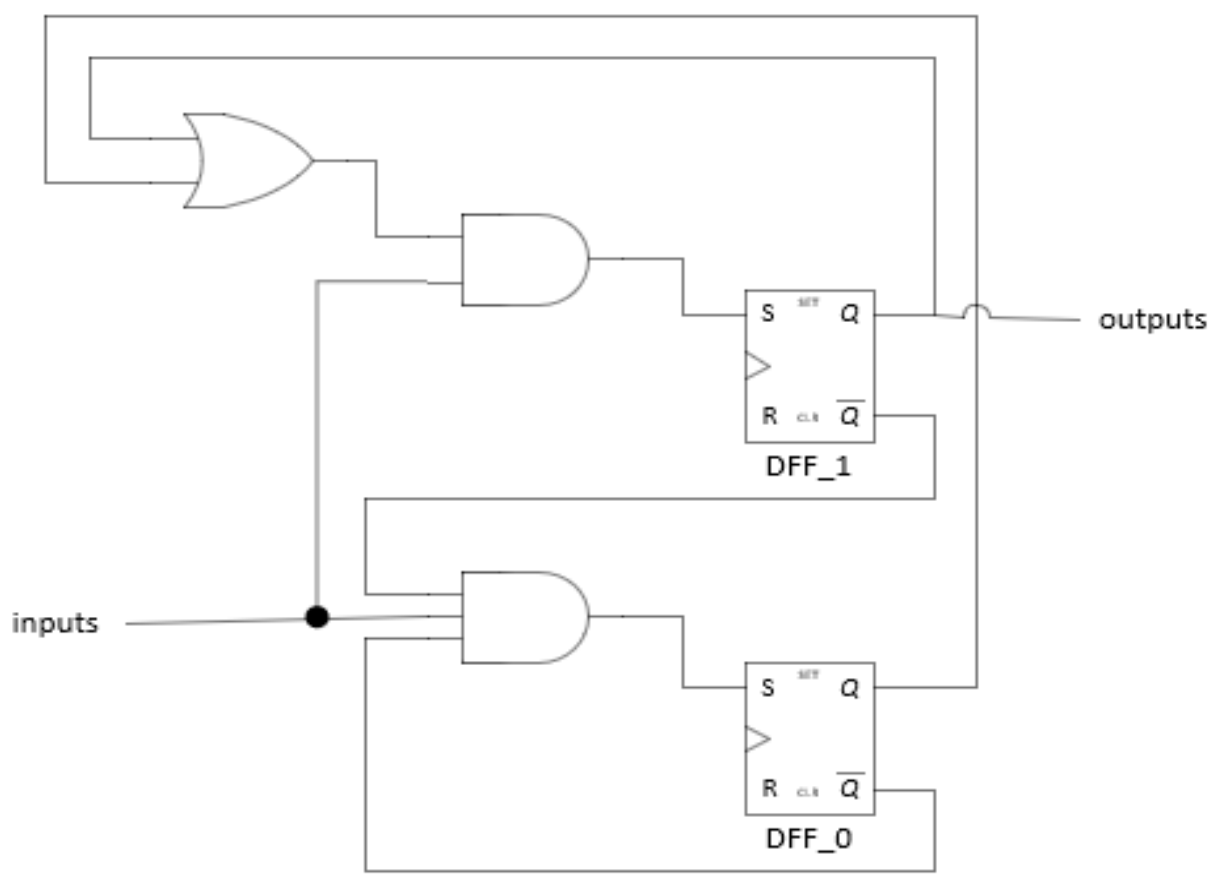

GAMbAR 5. Hasil Sintesis Manual Rangkaian FSM untuk Mendeteksi Urutan Input "11" 
Berdasarkan hasil sintesis manual, diperoleh rangkaian dengan penggunaan dua buah D flipflop, satu gerbang AND 2-input, satu gerbang AND 3-input, dan satu gerbang OR 2-input. Selanjutnya hasil sintesis file Verilog yang dihasilkan dapat dilihat pada Gambar 6 . Berdasarkan hasil sintesis file verilog dengan pilihan metode binary encoding, diperoleh rangkaian dengan dua buah D flip-flop, satu gerbang AND 2-input, satu gerbang OR 2input, dan satu gerbang NOT. Terdapat sedikit perbedaan dikarenakan adanya proses optimasi oleh aplikasi Intel Quartus Prime dan juga penyesuaian dengan teknologi perangkat keras yang digunakan. Akan tetapi, saat direkayasa balik akan menghasilkan diagram transisi yang sama sebagaimana ditunjukkan pada Gambar 7 .

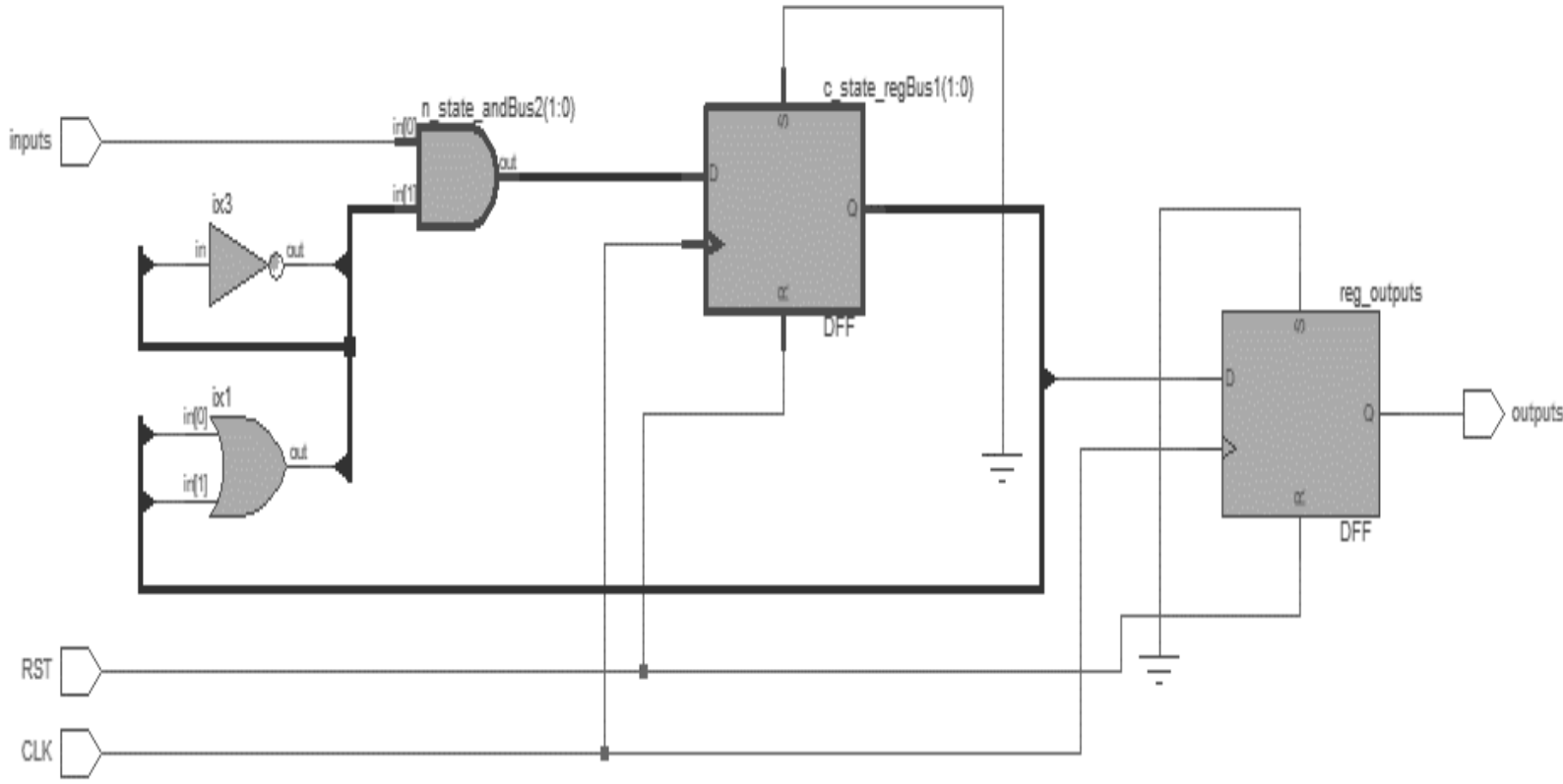

GAMBAR 6. Hasil Sintesis Rangkaian FSM Untuk Mendeteksi Urutan Input "11" Menggunakan Aplikasi Intel Quartus Prime

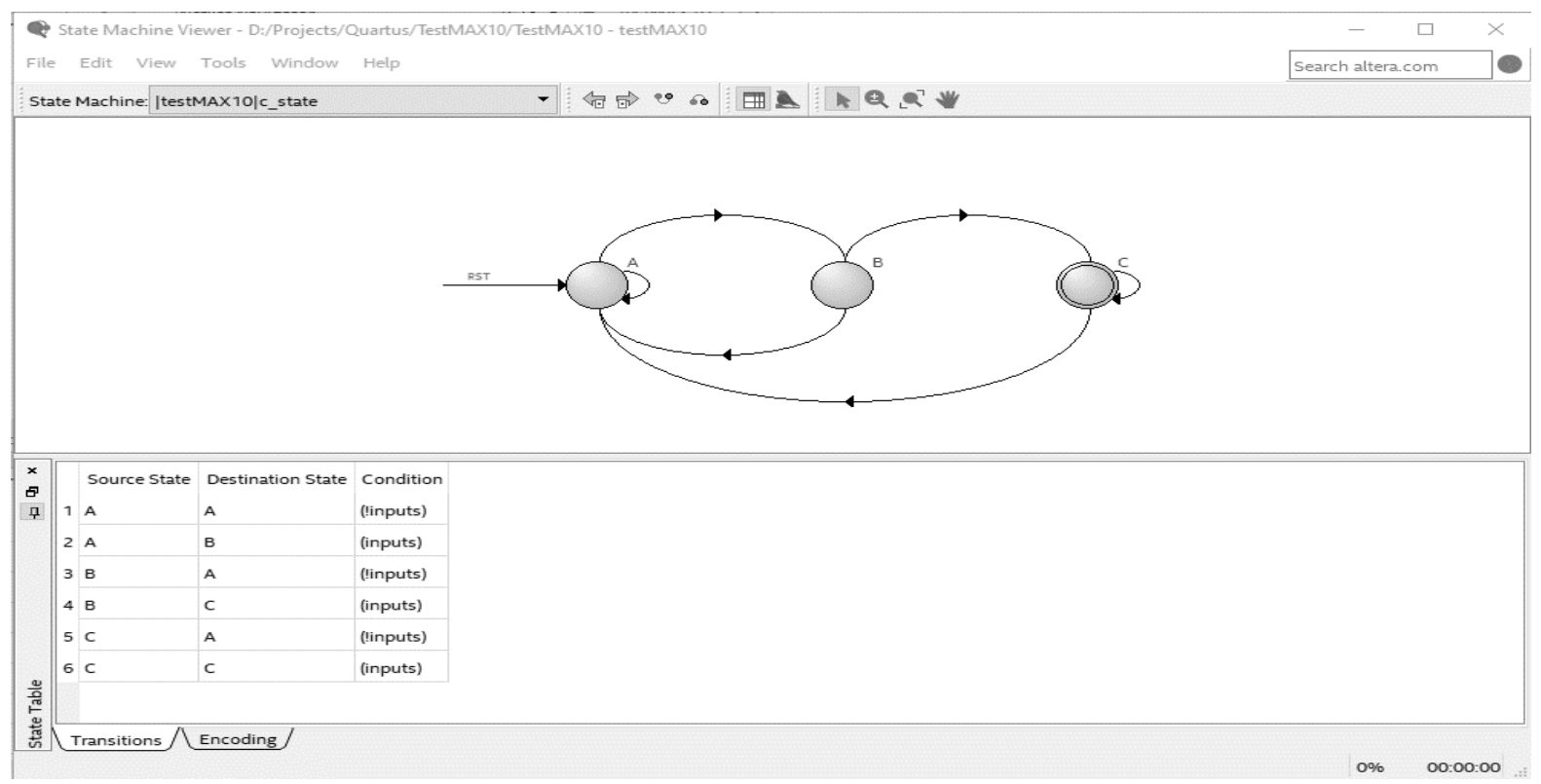

GAMBAR 7. Hasil Rekayasa Balik FSM Dari Rangkaian Hasil Sintesis Intel Quartus Prime 


\section{KESIMPULAN}

Sesuai dengan hasil pengujian fungsional, aplikasi FSM Designer berjalan dengan baik dengan kesesuaian $100 \%$ dengan rancangan yang ditetapkan. File Verilog yang dihasilkan oleh aplikasi juga sesuai dengan spesifikasi rangkaian FSM yang ditetapkan, sehingga aplikasi FSM Designer dapat digunakan untuk membantu otomasi proses perancangan FSM.

\section{DAFTAR PUSTAKA}

Brown, S., \& Vranesic, Z. (2014). Fundamentals of Digital Logic with Verilog Design (3 ed.). McGraw-Hill.

Bucaro, S. (2019). Basic Digital Logic Design: Use Boolean Algebra, Karnaugh Mapping, or an Easy Free Open-Source Logic Gate Simulator.

Donzellini, G., Oneto, L., Ponta, D., \& Anguita, D. (2019). Introduction to Digital Systems Design. Springer.

Hejlsberg, A., Wiltamuth, S., \& Golde, P. (2002). Standard ECMA-334: C\# Language Specification.

Hwang, E. O. (2005). Digital logic and Microprocessor Design with VHDL. La sierra University, Riverside.

IEEE Computer Society. (2006). IEEE Standard Verilog Hardware Description Language (Nomor IEEE Std $1364^{\mathrm{TM}}$ 2005). IEEE.

La Meres, B. J. (2017). Introduction to Logic Circuits \& Logic Design with Verilog. In Introduction to Logic Circuits \& Logic Design with VHDL. Springer. https://doi.org/10.1007/978-3-319-538839

Ledin, J. (2020). Modern Computer Architecture and Organization Learn x86, $A R M$, and RISC-V architectures and the design of smartphones, PCs, and cloud servers.

Martindale, J. (2021). What Is a CPU? Here's Everything You Need to Know | Digital Trends. Digital Trends. Retrieved from https://www.digitaltrends.com/computing /what-is-a-cpu/
Nachmanson, L., Pupyrev, S., Dwyer, T., Hart, T., \& Prutkin, R. (2021). Microsoft Automatic Graph Layout: A set of tools for graph layout and viewing. Microsoft Research. Retrieved from https://github.com/Microsoft/automaticgraph-layout.

Sutherland, S. (2001). Verilog-2001 Quick Reference Guide. Sutherland HDL.

Thomas, D. E., \& Moorby, P. R. (2013). The Verilog ${ }^{\circledR} \quad$ Hardware Description Language (3 ed.). Springer.

Weste, N. H. E., \& Harris, D. M. (2011). CMOS VLSI Design: A Circuits and Systems Perspective (4 ed.). Addison - Wesley.

PENUlis:

Fairuz Azmi

Program Studi Teknik Komputer, Fakultas Teknik Elektro, Universitas Telkom, Jl. Telekomunikasi Terusan Buah Batu, Bandung.

Email: worldliner@telkomuniversity.ac.id 